\title{
An Investigation of Shared Value, Benefit, Commitment, Trust and Retention in the Banking Sector: A Student Perspective
}

\author{
${ }^{*}$ Chinomona $\mathrm{E}^{1}$., Chinomona. $\mathrm{R}^{2}$, Sandada. $\mathrm{M}^{3}$ \\ ${ }^{1}$ Vaal University of Technology, South Africa \\ 2University of the Witwatersrand, South Africa \\ 3University of Zimbabwe, Zimbabwe \\ *chakubvae@hotmail.com
}

\begin{abstract}
Despite the increase in research focusing on service relationship level in the banking sector, research on relationship benefit, student perceived shared value on relationship commitment, trust and student retention in the African banking context is still scant. Therefore, using a data set of 175 from students in colleges and universities in Johannesburg, this study examines these relationships. Smart PLS software technique was used to statistically analyse the measurement and structural models. All the posited six hypotheses were supported. The findings from the data analysis proved that there is a strong positive relationship between all six hypotheses.
\end{abstract}

Keywords: Student perceived relationship benefit, student relationship commitment, student perceived shared value, student trust, student retention

\section{Introduction}

The ability to develop and sustain relationships with customers is a source of an added advantage in today's turbulent banking sector (Siu, Zhang, Dong \& Kwan, 2013). Different views have been suggested by different scholars to support the view that customer relationships are crucial to any business. Scholars such as Chen and $\mathrm{Hu}$ (2012) and Kim (2009) opine that it is cost efficient and effective to maintain old customers than to acquire new customers. Customers who are committed to a relationship may spread good information about the business and are keen to change. According to Siu et al, (2013), relationship partners feel obliged to reciprocate through commitment and loyalty to the relationship if they both perceive that they are benefiting from a relationship. Therefore the activities of players in the banking sector should be directed towards enhancing long term relationships. To achieve this, banks need to ensure that their services benefit customers (Wang \& Hsu, 2012), in order to enforce customer commitment to the relationship (Harrison, Beatty, Reynolds \& Noble, 2012). This will ensure customer trust (Yang \& Mossholder, 2010; Noor, 2012) and customer retention (Wang, 2008).

Although some research worked on the links between customer trust, commitment and retention in relationships, an investigation of conceptual models showing complex inter-linkages among these latent variables is still lacking. In the light of the dearth of research on this area, the study seeks to empirically tests relationships among customer perceived relationship benefit, perceived shared value of a relationship, customer commitment, trust and retention in the relationship. Specifically, the paper investigates the mediating influential role played by customer commitment to a relationship; customer perceived shared value with the service provider and customer trust on the relationship between perceived benefits of a relationship and customer retention in the relationship. To achieve this objective, this paper is grounded on the reciprocity theory. According to the reciprocity theory, relationship partners feel obliged to pay back to the other partner by being committed and loyal to each other if they feel that they do benefit from the relationship (Siu et al, 2013). As a contribution, the paper offers academic capital because it added knowledge on customer relationship. Results will be valuable to customer relationship managers as it provides some insights on maintaining good relationships with customers. First, literature review of the variables will be presented and this will be followed by the development of the hypotheses. Thereafter the methodology, data interpretation and conclusions are discussed. The final section presents the managerial implications, limitations and recommendations. 


\section{Literature Review}

Study reveal literature on five variables which are perceived relationship benefit, perceived shared value, relationship commitment, customer trust and customer retention.

Perceived relationship benefit: According to Siu et al (2013), perceived relationship benefit refers to the extent to which customers benefit from their relationship with the service provider. Kim (2009) views relational benefit as reciprocal because in service provision, service providers gain by benefiting customers. Relational benefit can be in the form of special treatment, confidence benefit and social benefit (Wang \& Hsu, 2012). In a special treatment benefit the service providers go out of their way to service customers, while in the confidence benefit situation, customers have trust in the service provider's ability to meet their expectations and the social benefits are realised because customers and service providers behave like friends as they have a lot in common (Wang \& Hsu, 2012; Harrison et al, 2012). In a similar vein, Hur, Park and Kim (2010) categorised relational benefit into four groups which are functional benefit (practical benefit that relationship partners get), economic benefit (price incentives), experiential benefits (happiness that is derived from a relationship) and symbolic benefit (the enhancement of one's image as a result of a relationship with the service provider).

Perceived shared value with the service provider: Wang (2008) defines perceived shared value as the degree to which one relationship partner has concern for the welfare of another partner. Customers' perception of shared value is enhanced by the service provider's commitment to devote resources, efforts and attention to the relationship (Wang, 2008). The service provider's commitment to a relationship signals an intention of goodwill and concern for the needs of customers (Ballantyne, Frow, Varey \& Payne, 2011). The authors proceed to state that there can only be a shared value if the exchange partners are reciprocally determined and communicate what is of value and if there are benefits to be gained and given up.

Relationship commitment: Marketing scholars have generally defined commitment to a relationship as the desire by both customers and service providers to sustain a relationship ( $\mathrm{Wu}, \mathrm{Zhou} \& \mathrm{Wu}, 2012$ ). The commitment to a relationship is based on the exchange theory whereby relationship partners make efforts to make sure that they sustain the relationship because it is very important to both of them (Siu et al, 2013). Harrison et al, (2012) state that customer commitment is affective (customer emotional attachment to the service provider), calculative (the relationship is beneficial) and normative (partners feel obligated to stay in a relationship). Noor (2012) operationalized customer commitment by using two dimensions namely affective commitment and continuance commitment. While affective commitment was described as customers' enjoyment of their membership with the service provider, continuance commitment was viewed as customers' appetite in maintaining a relationship.

Customer trust: Customer trust indicates the customers' reliance on the service provider due to confidence they have in the provider's ability to effectively complete tasks in a way that satisfies their need (Noor, 2012). Chang (2006), argued that trust could be affective (customers knows that the provider seeks to boost profits and customer need satisfaction) and cognitive (customers believe that the service provider is able to effectively fulfil promises). Scholars such as Dabholkar and Sheng (2012) and Olaru, Purchase and Peterson (2008) showed that customers develop trust in service providers if they have previous pleasurable experiences with the service provider. Therefore customer satisfaction has become an imperative as it is a precursor to customer commitment (Hong \& Cho, 2011). Sharing a similar view, Chang (2006) argue that ensuring customer trust is a strategic ingredient customer relationship construction. This shows how important customer trust is to the creation of customer relationship to the banking sector.

Customer retention: The competitive conditions in the market place have necessitated the need for the banking sector to invest in activities that enforce customer retention (Boshoff \& du Plessis, 2009). Service provider should ensure that customers make repeat purchases consistently despite efforts by competitors to influence their behaviour (Deng, Lu, Wei \& Zhang, 2010). For customers not to switch off to other supplier, they need to be psychologically and attitudinally attached to the supplier (Hong \& Cho, 2011). When this happens, customers become loyal and committed to the relationship (Lee, 2010). It is consistent with views by other scholars such as Deng et al. (2010) and Boshoff and du Plessi (2009) who pointed out that it is beneficial to retain existing customers because they spread positive information and 
they make referrals. In the light of above discussion, the next section presents the conceptual framework showing how these constructs are related.

Conceptual Hypothesis Development: Figure 1 shows the conceptual model. As discussed in preceding section, the model is comprised of five latent variables. They include perceived relationship benefit, perceived shared value, relationship commitment, customer trust and retention. The linkages among the proposed variables in the conceptual model are as follows, perceived relationship benefit, perceived shared value, relationship commitment and customer trust positively influence customer retention. Hypotheses were then developed to explain in detail the relations among these variables.

Figure 1: Conceptual Model

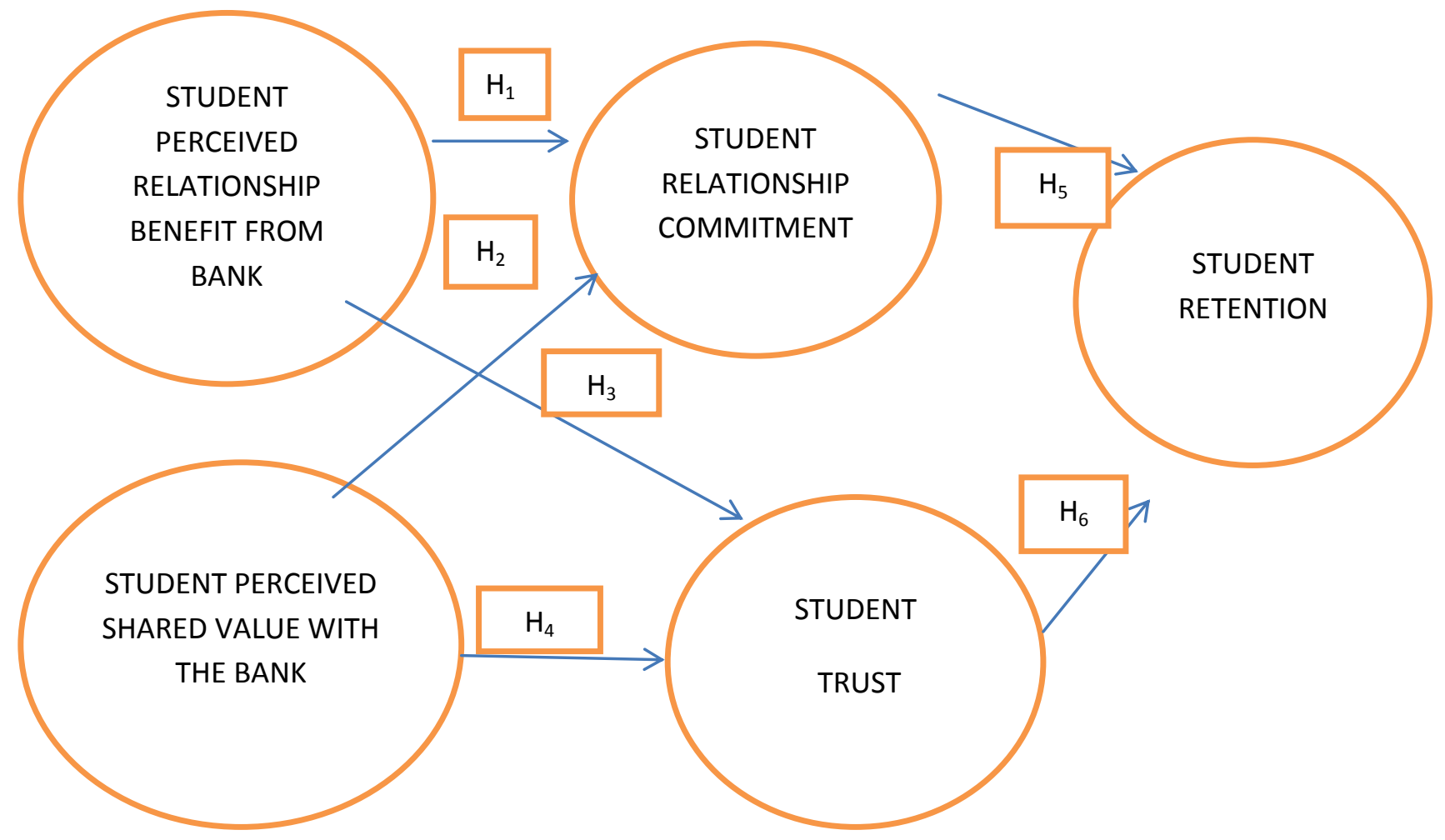

Perceived relationship benefit and customer relationship commitment: The students' perceived benefit from a relationship with the bank is a necessary condition for their commitment to the relationship (Siu et al, 2013). The more students perceive that they enjoy the confidence, social and special treatment benefits from the bank, and the more is their commitment to the relationship (Kim, 2009).Wu et al, (2012) proved that there is a positive relationship between perceived relationship benefit and relationship commitment. Other scholars also present findings indicating a positive between perceived relationship benefit and commitment to a relationship (Harrison et al, 2012; Hur et al, 2010). Therefore the following hypothesis was developed:

H1: The Higher the relationship benefit, the higher the commitment to the relationship

Perceived relationship benefit and customer trust: According to Kim (2009), customers' confidence, familiarity and pleasurable experiences lead to trust in the service provider. The findings of a study by Dagger, David and Ng (2011), suggest social and special benefits that customers enjoy in a relationship have an influence on their confidence in the service provider. In that vein, Chen and Hu (2012) argue that customer trust in the service provider strengthens if they perceive that they benefit from a given service provider relative to what they could from rival service providers. In the same way, Wang (2008) suggest perceived benefit leads to a higher level of customer trust due to mutual trust between the relationship partners. In the light of these views, the study proposed that:

H2: Perceived relationship positively impacts on customer trust

Perceived shared value and relationship commitment: According to Wang (2008), if partners in a relationship have concern for the welfare of one another, both partners become committed to the 
relationship because there is a general feeling that they share the same values. Rafiq, Fulford and Lu (2013) also present results showing that the perceived shared value has an influence on commitment. The results further show that the service provider's investment of time, effort and money in the relationship is an indication of good will to the values and needs of customers and this persuades customers to be committed to the relationship. This corroborates Dos Santos and Basso's (2012) finding which indicates that an ongoing relationship between customers and the service provider leads to relationship commitment by both parties. There the following hypothesis id developed:

H3: Perceived shared value positively influences customer commitment to the relationship

Perceived shared value and customer trust: Customer trust in the service provider strengthens when there are high levels of perceived shared value in the relationship (Rafiq et al, 2013). The more one relationship partner is concerned about the values of another partner, the stronger is the trust between the partners (Wang, 2008). Rafiq et al, (2013) further state that if customers realise that the service provider has invested a lot of resources in the relationship, they become more confident that the service provider is genuinely intending to maximise the profits as well as their needs. Based on these insights, the study developed the following hypothesis:

H4: Students' perceived shared value with the bank has a positive effect on their trust

Student relationship commitment and student retention: Dagger et al., (2011) study underscores the role commitment plays in creating customer retention by stating that customers who are willing to maintain the relationship are likely to have high levels of loyalty to the relationship. Wu et al., (2012) also found that customer commitment to a relationship has an effect of consolidating their willingness to remain in the relationship. Similarly, Wang (2008) state that customers who are committed to a relationship do resist attempts by rival service providers to change their loyalty by making repeat purchases from the chosen service provider. Committed customers also make referrals, pay premium prices and are willing to try new products (Rafiq et al., 2013). Based on this reasoning, it is hypothesised that:

H5: Customer relationship commitment positively influences customer retention.

Customer trust and customer retention: According to Wang (2008), customer trust is hypothesised to positively influence customer retention because customer trust reduces perceived risk. Dos Santos and Basso (2012) suggest that if customers have confidence in the ability of the supplier, they are willing to remain loyal to the supplier for a long time. Noor (2012) argued that there is a positive correlation between customer trust and customer retention. He recommended that service providers need to consolidate customer trust by taking care of their needs. A study by Lee (2010) indicates that customer generally develop trust and are willing to remain in relationships with service providers who are operationally competent, benevolent and trustworthy. This shows how vital customer trust is to create and sustain customer retention. The study therefore develops the following hypothesis:

H6: Customer trust positively influences customer retention

\section{Methodology}

Target population for the study was university students in Johannesburg who have accounts with different banks like Nedbank, Standard Chartered Bank, ABSA, FNB and POSB. The sampling unit was the individual students who are account holders. "Relationship benefit" measure used four-item scales adapted from Morgan \& Hunt (1994). "Relationship commitment" used five-item scale measure all adapted from Wu et al., (2012), "Student trust" used six -item scale measure adapted from Kabadayi and Ryu (2007). "Students Shared value" used a five questionnaires adopted from Morgan and Hunt (1994). All the measurement items were measured on a five-point Likert-type scale.

Respondent Profile: Table 1 presents the description of the participants. The respondents were asked to report their demographic information, including gender, age, marital status and education. The respondents were predominantly females (57\%). The mode age group of the respondent was that of less than 30 years (51\%). $63 \%$ of the respondents were single. $57 \%$ of the respondents diploma students, $17 \%$ were bachelor's students, 14 percent had masters degrees and $12 \%$ were doctorate students. 
Table 1: Sample Demographic Characteristics

\begin{tabular}{lll}
\hline Gender & Frequency & Percentage \\
\hline Male & 76 & 43 \\
Female & 99 & 57 \\
Total & 175 & 100 \\
Age & Frequency & Percentage \\
Less than or equal to 30 years & 90 & 51 \\
30-50 years & 50 & 29 \\
More than 50 years & 35 & 20 \\
Total & 175 & 100 \\
& & \\
Marital status & Frequency & Percentage \\
Married & 65 & 37 \\
Single & 110 & 63 \\
Total & 175 & 100 \\
Level of education & Frequency & Percentage \\
Diploma & 100 & 57 \\
Bachelor's degree & 30 & 17 \\
Master's degree & 25 & 14 \\
Doctorate students & 20 & 12 \\
Total & 175 & 100 \\
\hline
\end{tabular}

\section{Data Analysis}

This study used Smart PLS software for Structural Equation Modeling (SEM) technique (Ringle, Wende \& Will 2005). Since the sample size small (175) Smart PLS was found to be more useful to use in study. Below is Table 2 presenting evidence on the reliability and validity. As can be seen (Table 2), all items have loadings greater than 0.6 (i.e. ranging from 0.570 to 0.848 ), while t-statistics derived from bootstrapping (200) resample's suggest all loadings are significant at p-value, 0.01 . As such, this confirms that all the measurement items converged well on their respective constructs and therefore are statistically significant.

Table 2: Data Analysis Results

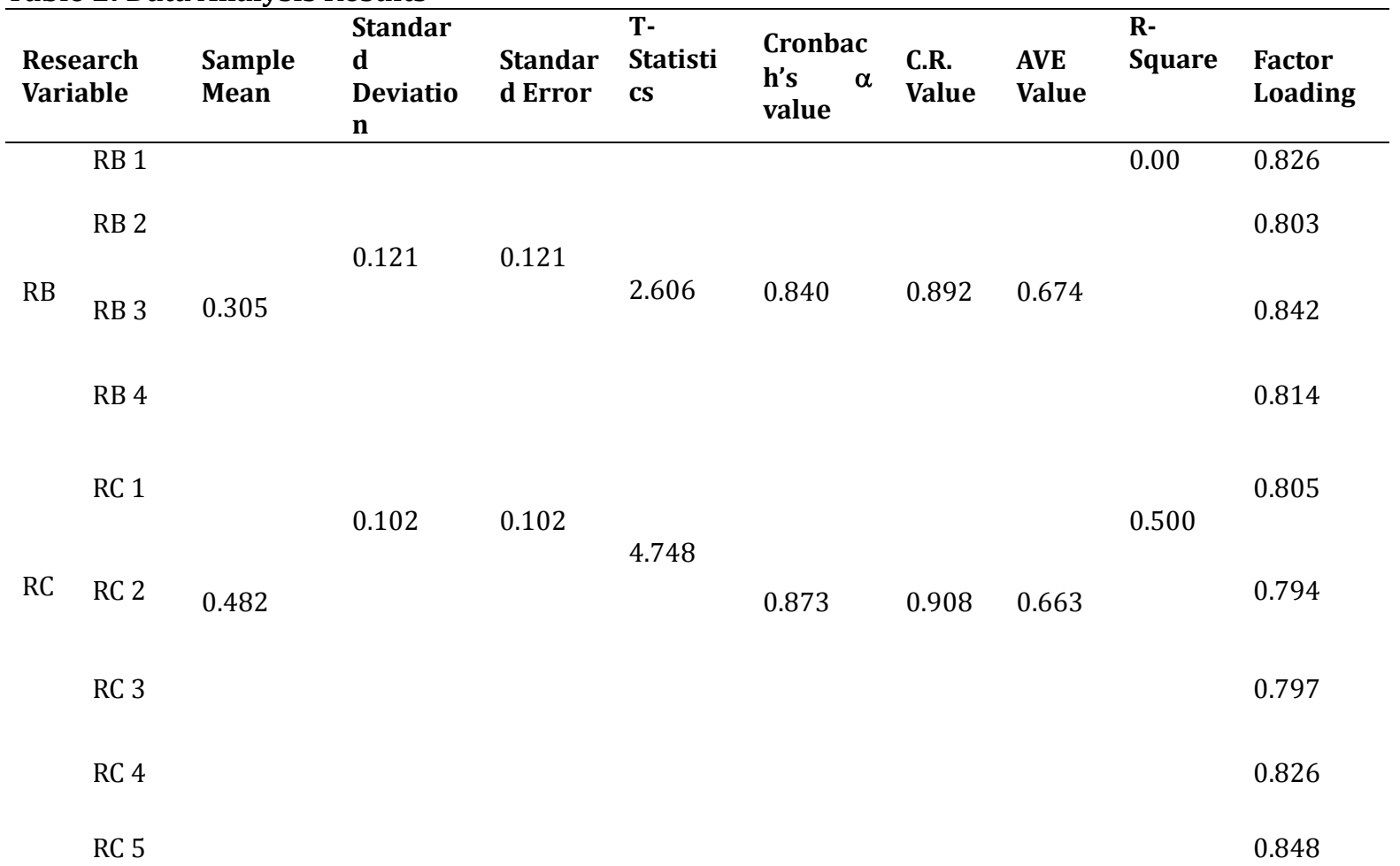



$S V=S t u d e n t$ Perceived Shared Value with the Bank; RT=Student Trust; $C R=$ Student Retention.

Chin (1998), showed that research variables should have an average variance extracted (AVE) of more than 0.5 and a composite reliability of more than 0.7 (convergent validity), and inter-construct correlations should be less than the square-root of the AVE (discriminant validity). As can be seen (Table 3 ), AVE and CR are generally equal or greater than 0.5 and 0.8 , respectively.

Table 3: Correlations between Constructs

\begin{tabular}{llllll}
\hline Research Constructs & CR & RB & RC & RT & SV \\
\hline CR & 1.000 & & & & \\
RB & 0.717 & 1.000 & & & \\
RC & 0.723 & 0.623 & 1.000 & & \\
RT & 0.678 & 0.666 & 0.686 & 1.000 & \\
SV & 0.710 & 0.753 & 0.646 & 0.770 & 1.000 \\
\hline
\end{tabular}

Note: RB=Student Perceived Relationship Benefit from Bank; RC=Student Relationship Commitment; $S V=$ Student Perceived Shared Value with the Bank; RT=Student Trust; CR=Student Retention

Path Model: The standardized path coefficients are expected to be at least 0.2 , and preferably greater than 0.3 (Chin 1998; Chin \& Newsted 1999). Note: SL = Service Quality Level; CF = Consumer Fantasy; EL $=$ Emotional Loyalty. The results in Figure 2 show that all are statistically significant. 
Table 4: Results of Structural Equation Model Analysis

\begin{tabular}{|c|c|c|c|c|c|}
\hline $\begin{array}{l}\text { Proposed } \\
\text { Relationship }\end{array}$ & Hypothesis & Hypothesis & $\begin{array}{l}\text { Path } \\
\text { Coefficients }\end{array}$ & T-Statistics & $\begin{array}{l}\text { Rejected/ } \\
\text { Supported }\end{array}$ \\
\hline $\mathrm{RB}$ to $\mathrm{RC}$ & & H1 & 0.316 & 2.602 & Supported \\
\hline $\mathrm{SV}$ to $\mathrm{RC}$ & & $\mathrm{H} 2$ & 0.200 & 2.359 & Supported \\
\hline $\mathrm{RB}$ to $\mathrm{RT}$ & & H3 & 0.409 & 3.395 & Supported \\
\hline $\mathrm{SV}$ to $\mathrm{RT}$ & & $\mathrm{H} 4$ & 0.620 & 7.172 & Supported \\
\hline $\mathrm{RC}$ to $\mathrm{CR}$ & & H5 & 0.487 & 4.748 & Supported \\
\hline $\mathrm{RT}$ to $\mathrm{CR}$ & & H6 & 0.344 & 3.193 & Supported \\
\hline
\end{tabular}

Note: RB=Student Perceived Relationship Benefit from Bank; RC=Student Relationship Commitment; $S V=$ Student Perceived Shared Value with the Bank; RT=Student Trust; $C R=$ Student Retention

Overall, $\mathrm{R}^{2}$ for RB, RC, SV, RT and CR in Figure 2, indicate that more than $20 \%$ and $62 \%$ respectively of the variance is explained. Tenenhaus, Vinzi, Chatelin \& Lauro, (2005) provided the formula of the global goodness-of-fit (GoF) statistic. Calculated global goodness of fit (GoF) is 0.66, which exceed the cut off point of GoF>0.36 suggested by Wetzels, Odekerken-Schröder \& van Oppen (2009). This shows that the research model has a good overall acceptance level.

Figure 2: Structural Model Results

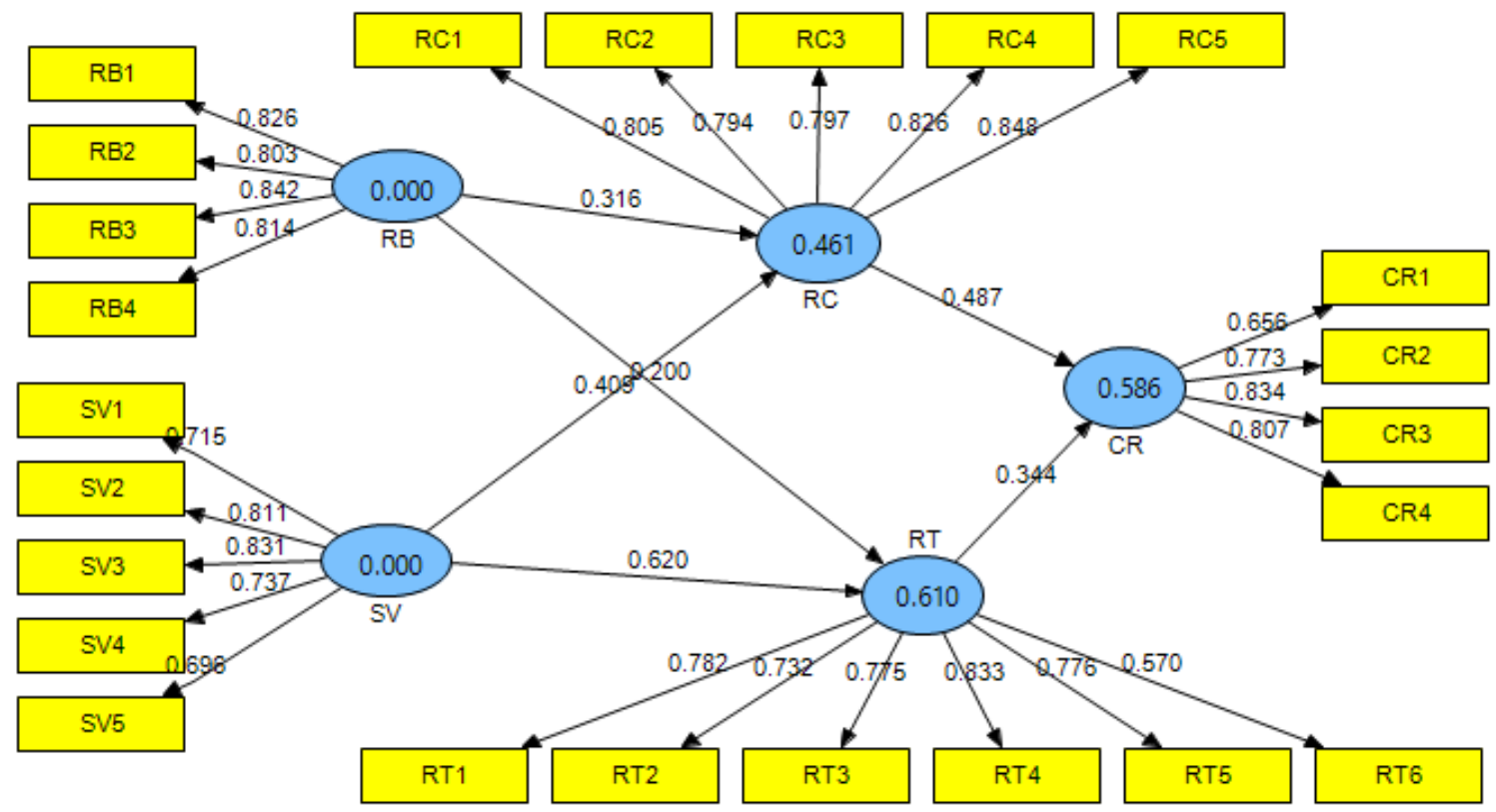

Note: RB=Student Perceived Relationship Benefit from Bank; RC=Student Relationship Commitment; $S V=S t u d e n t$ Perceived Shared Value with the Bank; RT=Student Trust; CR=Student Retention

The results shows that all the six relationships (i.e. H1, H2, H3, H4, H5, H6) are supported by the data. Figure 2 and Table 4 provide the path coefficients for H1 to H6 (i.e. 0.200 to 0.620 ).

Discussion of Results: Results in Table 4 and Figure 1 provide support for the six hypotheses (H1 to H6). Hypothesis 1 posited a positive relationship between students perceived relationship benefit from bank and student relationship commitment. The result in Table 5.3 and Figure 5.1, indicates that there is a significant $(\mathrm{t}=2.602)$ positive (beta $=0.316)$ relationship between student perceived relationship benefit from bank. Hypothesis 2 shows a positive association between students perceived shared value with the bank and student relationship commitment. Hypothesis 2, results indicated that the relationship between student perceived shared value with the bank with student relationship commitment (beta $=0.200$ ) is positive and that relationship is significant $(\mathrm{t}=2.359)$. Thus, a higher level of student perceived shared value with the bank is associated with a high student relationship commitment. Hypothesis 3 posited a positive relationship between students perceived relationship benefit from bank and student trust. Figures shows there is a significant $(t=3.395)$, positive (beta $=0.409$ ) relationship between student perceived benefit from bank and student trust. 
Hypothesis 4, results indicated that the relationship between student perceived shared value with the bank with student trust (beta $=0.620)$ is very strong and that relationship is very significant $(\mathrm{t}=7.172)$ compared to other relationships. This is the strongest relationship for all the six relationships in this study. The higher level of student perceived shared value with the bank is associated with a high student trust. There is a positive association between student relationship commitment and student retention. H5 results indicated the relationship between student relationship commitment with student retention (beta $=0.487)$ is strong and that relationship is significant $(\mathrm{t}=4.748)$.A higher level of student relationship commitment is associated with a higher student retention. Hypothesis 6 posited a positive relationship between student trust and student retention. Consistent with H6, the result in Table 5.3 and Figure 5.1, indicates that there is a significant $(\mathrm{t}=3.193)$ positive (beta $=0.344)$ relationship between student trust and student retention. This shows that the higher the student trust the higher the student retention in the bank. Therefore, H6 is supported.

\section{Conclusion and Recommendations}

The aim of this study was to investigate the mediating role played by customer commitment to a relationship; customer perceived shared value with the service provider and customer trust on the relationship between perceived benefits of a relationship and customer retention in the relationship. To achieve this objective, this paper is grounded on the reciprocity theory. According to the reciprocity theory, relationship partners feel obliged to pay back to the other partner by being committed and loyal to each other if they feel that they do benefit from the relationship (Siu et al, 2013). The results supported all the six hypotheses in a significant way. South Africa is still a developing country and many researches on these variables have been conducted in the developed world. This study makes a significant contribution to the student perceived relationship benefit from banks and student perceived shared value with the bank in a developing country context. This study submits that bank managers should try to allure students trust and make sure that they do not leave them for other banks. First, the research was done in Johannesburg with sample size of 175 which is small. Other researchers might do the same research using large data samples of about 300 and above. In this case they might be able to use other comprehensive data analytical techniques like Structural Equation Modeling. Future studies may be conducted by using data from other cities in South Africa which may include Pretoria, Cape Town and Durban. Second, data from two different countries might be collected to do comparisons. This might confirm or disconfirm the results obtained

\section{References}

Boshoff, C. \& Du Plessis, F. (2009). Services Marketing: A Contemporary Approach. Cape Town. Juta and Company Ltd.

Ballantyne, D., Frow, P., Varey, R. J. \& Payne, A. (2011). Value propositions as communication practice: Taking a wider view. Industrial Marketing Management, 40(2), 202-210.

Chang, J. C. (2006). Customer Satisfaction with Tour Leaders' Performance: A Study of Taiwan's Package Tours. Asia Pacific Journal of Tourism Research, 11(1), 97-116.

Chen, P. T. \& Hu, H. H. S. (2012). The mediating role of relational benefit between service quality and customer loyalty in airline industry. Total Quality Management \& Business Excellence, 2, 1-12.

Chin, W. W. (1998). Issues and opinion on structural equation modelling. MIS Quarterly, 22(1), 7-16.

Chin, W. W. \& Newsted, P. R. (1999). Structural equation modelling analysis with small samples using partial least squares. In Rick Hoyle (ed). Statistical Strategies for Small Sample Research. Thousand Oaks, CA: Sage. pp. 307-341.

Dabholkar, P. A. \& Sheng, X. (2012). Consumer Participation in Using Online Recommendation Agents: Effects on Satisfaction, Trust, and Purchase Intentions. The Service Industries Journal, 32(9), 1433-1449.

Dagger, T. S., David, M. E. \& Ng, S. (2011). Do relationship benefits and maintenance drive commitment and loyalty? Journal of Services Marketing, 25(4), 273-281.

Deng, Z., Lu, Y., Wei, K. K. \& Zhang, J. (2010). Understanding Customers Satisfaction and Loyalty: An empirical study of mobile Instant messages in China. International Journal of Information Management, 30(2010), 289-300.

Dos Santos, C. P. \& Basso, K. (2012). Do ongoing relationships buffer the effects of service recovery on customers' trust and loyalty? International Journal of Bank Marketing, 30(3), 168-192. 
Harrison, M. P., Beatty, S. E., Reynolds, K. E. \& Noble, S. M. (2012). Why Customers Feel Locked Into Relationships: Using Qualitative Research to Uncover the Lock-in Factors. The Journal of Marketing Theory and Practice, 20(4), 391-406.

Hong, I. B. \& Cho, H. (2011). The Impact of Consumer Trust on Attitudinal Loyalty and Purchase Intention in B2C E-marketplace: Intermediary Trust versus Seller Trust. International Journal of Information Management, 31, 469-479.

Hur, W. M., Park, J. \& Kim, M. (2010). The role of commitment on the customer benefits-loyalty relationship in mobile service industry. The Service Industries Journal, 30(14), 2293-2309.

Kabadayi, S. \& Ryu, S. (2007). The protection of the trust or through the use of control mechanisms and its performance implications. Journal of Business and Industrial Marketing, 22(4), 260-271.

Kim, W. (2009). Customers' Responses to Customer Orientation of Service Employees in Full-Service Restaurants: A Relational Benefits Perspective. Journal of Quality Assurance in Hospitality \& Tourism, 10(3), 153-174.

Lee, H. S. (2010). Factors Influencing Customer Loyalty of Mobile Service: Empirical Evidence from Koreans. Journal of International Banking and Commerce, 15(2), 1-14.

Morgan, R. M. \& Hunt, S. D. (1994). The Commitment-Trust Theory of Relationship Marketing. Journal of Marketing, 58(5), 20-38.

Noor, N. A. M. (2012). Trust and Commitment: Do They Influence E-Customer Relationship Performance? International Journal of Electronic Commerce, 3(2), 281-296.

Olaru, D., Purchase, S. \& Peterson, N. (2008). From Customer Value to Repurchase Intentions and Recommendations. Journal of Business and Industrial Marketing, 23(8), 558-565.

Rafiq, M., Fulford, H. \& Lu, X. (2013). Building customer loyalty in online retailing: The role of relationship quality. Journal of Marketing Management, 29(3-4), 494-517.

Ringle, C. M., Wende, S. \& Will, A. (2005). SmartPLS 2.0 M3. Available at http:// www.smartpls.de. Accessed 23/03/2013

Siu, N. Y. M., Zhang, T. J. F., Dong, P. \& Kwan, H. Y. (2013). New service bonds and customer value in customer relationship management: The case of museum visitors. Tourism Management, 36, 293303.

Tenenhaus, M., Vinzi, V. E., Chatelin, Y. M. \& Lauro, C. (2005). PLS Path Modeling. Computational Statistics and Data Analysis, 48(1), 159-205.

Wang, W. H. (2008). The interrelationship of retailer's relationship efforts and consumers' attitude and behavior. Measuring Business Excellence, 12(1), 13-28.

Wang, C. H. \& Hsu, L. C. (2012). How do Service Encounters Impact on Relationship Benefits. International Business Research, 5(1), 98-109.

Wetzels, M., Odekerken-Schröder, G. \& Van Oppen, C. (2009). Using PLS path modelling for assessing hierarchical construct models: Guidelines and empirical illustration.

$\mathrm{Wu}, \mathrm{X}$., Zhou, H. \& Wu, D. (2012). Commitment, satisfaction, and customer loyalty: a theoretical explanation of the 'satisfaction trap. The Service Industries Journal, 32(11), 1759-1774.

Yang, J. \& Mossholder, K. W. (2010). Examining the effects of trust in leaders: A bases-and-foci approach. Leadership Quarterly, 21, 50-63. 